\title{
Well Installation Report for Monitoring Wells TCM4, TCM5, and TCM8 and Pilot Hole TGSC-2A
}

by

R. L. Nichols

Westinghouse Savannah River Company

Savannah River Site

Aiken, South Carolina 29808

J. V. Noonkester

This paper was prepared in connection with work done under the above contract number with the U.S. Department of Energy. By acceptance of this paper, the publisher and/or recipient acknowledges the U.S. Government's right to retain a nonexclusive, royalty-free license in and to any copyright covering this paper, along with the right to reproduce and to authorize others to reproduce all or part of the copyrighted paper. 
WSRC-TR-98-00247

Revision 0

\title{
Well Installation Report -.
}

\author{
for Monitoring Wells \\ TCM4, TCM5 and TCM8 \\ and Pilot Hole TGSC-2A (U)
}

July 1,1998

R. L. Nichols

J. V. Noonkester

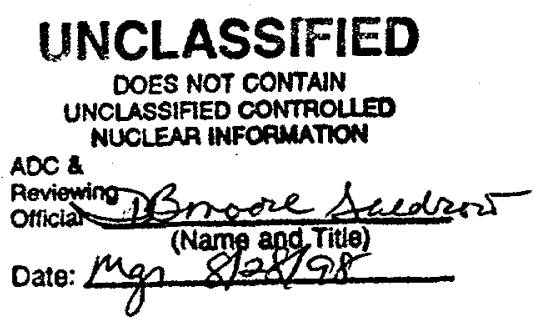

Westinghouse Savannah River Company

Savannah River Site

Aiken, SC

Prepared for the U. S Department of Energy under contract no. DE-AC09-96SR18500 


\section{DISCLAIMER}

This report was prepared as an account of work sponsored by an agency of the United States Government. Neither the United States Government nor any agency thereof, nor any of their employees, makes any warranty, express or implied, or assumes any legal liability or responsibility for the accuracy, completeness, or usefulness of any information, apparatus, product, or process disclosed, or represents that its use would not infringe privately owned rights. Reference herein to any specific commercial product, process, or service by trade name, trademark, manufacturer, or otherwise does not necessarily constitute or imply its endorsement, recommendation, or favoring by the United States Government or any agency thereof. The views and opinions of authors expressed herein do not necessarily state or reflect those of the United States Government or any agency thereof.

This report has been reproduced directly from the best available copy.

Available to DOE and DOE contractors from the Office of Scientific and Technical Information, P.O. Box 62, Oak Ridge, TN 37831; prices available from (615) 576-8401.

Available to the public from the National Technical Information Service, U.S. Department of Commerce, 5285 Port Royal Road, Springfield, VA 22161. 


\section{DISCLAIMER}

Portions of this document may be illegible in electronic image products. Images are produced from the best available original document. 


\section{Table of Contents}

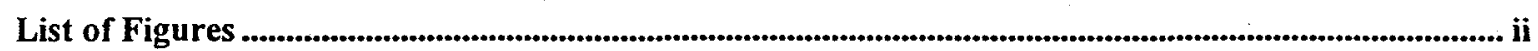

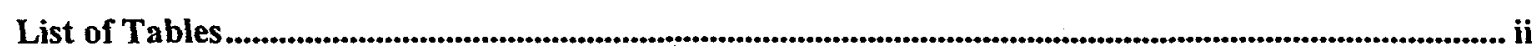

Appendices

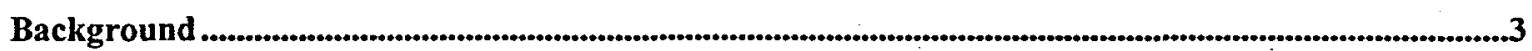

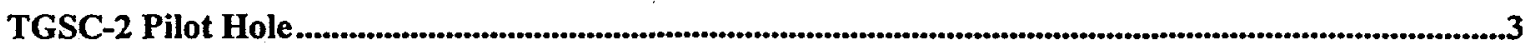

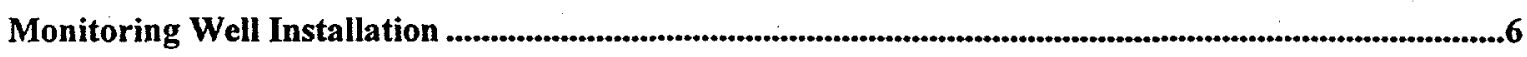

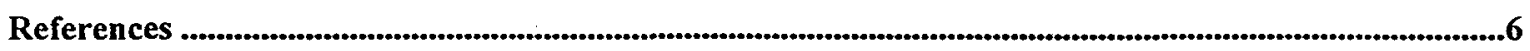




\section{List of Figures}

Figure 1 Geophysical log and trichloroethylene profile for TGSC-2A.................................................7

Figure 2 Monitoring well construction diagram for monitoring well TCM4 . ............................................8

Figure 3 Monitoring well construction diagram for monitoring well TCM5...........................................9

Figure 4 Monitoring well construction diagram for monitoring well TCM8. ........................................10

\section{List of Tables}

Table 1 Results from headspace analysis of bulk sediment samples collected from the TGSC-2A pilot

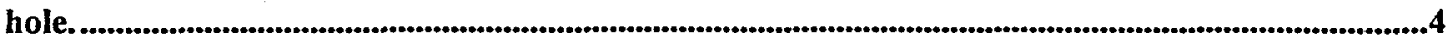

Table 2 Well construction details for monitoring wells TCM4, TCM5, and TCM8 and pilot hole

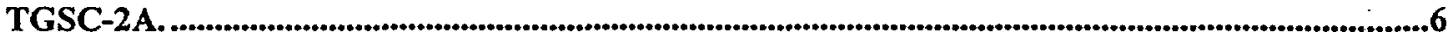

\section{Appendices}

Appendix A Field Geologic Log for Pilot Hole TGSC-2A 


\section{Background}

The shallow groundwater and sediments beneath the TNX Area are contaminated with both dissolved and residual chlorinated volatile organic compounds (CVOCs) such as trichloroethylene (TCE), carbon tetrachloride and perchloroethylene (PCE)..The Savannah River Technology Center (SRTC) is studying a new technology for remediating CVOCs known as GeoSiphon. The GeoSiphon Cell is a large diameter well uses granular cast iron for filter pack material and is operated by inducing a siphon to draw contaminated groundwater through the iron filter pack. As groundwater flows through the granular cast iron CVOCs are reduced to ethane, ethene, methane, and chloride ions. Previous laboratory and field studies (ETI, 1996, and Phifer et. al., 1997) conducted by SRTC have shown that granular cast iron is capable of remediating contaminated at TNX. SRTC will be conducting a Dual Cell test of the GeoSiphon technology in 1999 to study the hydraulic interaction of multiple cells operating simultaneously.

This report documents the installation of 3 monitoring wells and 1 pilot hole that were installed to support the Dual phase test. The three monitoring wells will be used to study the hydraulic interaction between the 2 GeoSiphon cells. Continuous core was collected from the proposed location for the second GeoSiphon Cell TGSC-2. Depth discrete samples collected from the core were analyzed for CVOCs.

\section{TGSC-2A Pilot Hole}

Continuous core was collected to a depth of 52 feet at the TGSC-2A location using steam cleaned hollow stem augers and split spoon sampling tubes. The total depth of the core was determined by the location of the confining layer at the base of the unconfined aquifer. Depth discrete bulk sediment samples were collected from TGSC-2A core, Table 1. Once the core had been removed from the ground, $3-5 \mathrm{~cm}^{3}$ samples of the bulk sediment were immediately collected at 2 feet intervals and at significant lithologic changes using a modified plastic syringe. The samples were transferred to $22.5 \mathrm{~mL}$ glass vials and $7.5 \mathrm{~mL}$ of deionized water was added to each vial as a suspending solution. Each vial was then sealed with a Teflon $\circledast$ lined rubber septa and aluminum crimp top. All samples were refrigerated until analysis. After the depth discrete bulk sediment samples had been collected the geologist providing technical oversight of the drilling prepared a detailed lithologic description of the core, (Appendix A).

Prior to sampling the average weight of 10 each $22.5 \mathrm{~mL}$ glass vials with $7.5 \mathrm{~mL}$ pure deionized water and a Teflon lined rubber septa and aluminum crimp top (tare) was determined to be $21.79 \mathrm{gm}$. The weight of the sediment sample was determined by weighing the sealed sample bottle and subtracting the average tare weight. Each sample was then analyzed using a Hewlett Packard (HP) 5890 gas chromatograph (GC) equipped with an electron capture detector, a flame ionization detector, an HP 19395 headspace sampler, and a $60 \mathrm{~m}$ widebore capillary column coated with a nonpolar silicone phase. The samples are heated to 70 degrees $\mathrm{C}$ in the autosampler prior to injection into the $\mathrm{GC}$ to maximize the transfer of CVOCs into the vapor phase (Looney et al, 1993). A complete set of standards was run with each set of samples for calibration. This method is a slightly modified version of the newly approved EPA Method 5021 (EPA, 1995) for headspace analysis of CVOCs in soil and water samples.

Results of the depth discrete sediment sampling and analysis Table 1, show that there are residual CVOCs present in the saturated sediments at the TGSC-2A location. Figure 1 contains contaminant profile for CVOCs in the TGSC-2A pilot hole. These results are similar to the contaminant profile reported by Phifer et. al., 1997. A geophysical log of the pilot hole was conducted to measure natural gamma, spontaneous potential (SP), and resistivity of the sediments around the borehole and a caliper log was performed to measure the diameter of the borehole, Figure 1. 
Table 1 Results from headspace analysis of bulk sediment samples collected from the TGSC-2A pilot hole.

\begin{tabular}{|c|c|c|c|c|c|}
\hline \multirow[b]{2}{*}{ Depth (ft) } & \multirow{2}{*}{$\begin{array}{c}\text { Sample } \\
\text { Weight (gm) }\end{array}$} & \multicolumn{4}{|c|}{$\mathrm{mg} / \mathrm{kg}$} \\
\hline & & c-dce & ccl4 & tce & pce \\
\hline 1 & 1.91 & $<1.4 \mathrm{E}-02$ & $<3.6 \mathrm{E}-05$ & $<1.3 \mathrm{E}-04$ & - $6.22 \mathrm{E}-04$ \\
\hline 2 & 4.70 & $<1.4 \mathrm{E}-02$ & $<3.6 \mathrm{E}-05$ & 5.73E-04 & 1.37E-03 \\
\hline 3 & 3.74 & $<1.4 \mathrm{E}-02$ & $<3.6 \mathrm{E}-05$ & 1.10E-03 & $1.84 E-03$ \\
\hline 4 & 4.37 & $<1.4 \mathrm{E}-02$ & $<3.6 E-05$ & $1: 63 E-03$ & $1.48 E-03$ \\
\hline 4.5 & 4.90 & $<1.4 \mathrm{E}-02$ & $<3.6 \mathrm{E}-05$ & $2.74 \mathrm{E}-03$ & 6.17E-04 \\
\hline 5 & 4.28 & $<1.4 \mathrm{E}-02$ & $<3.6 \mathrm{E}-05$ & $2.58 \mathrm{E}-02$ & 4.17E-04 \\
\hline 6.5 & 4.22 & $<1.4 \mathrm{E}-02$ & $2.94 \mathrm{E}-04$ & 2.83E-02 & $5.66 \mathrm{E}-04$ \\
\hline 7 & 3.51 & $<1.4 \mathrm{E}-02$ & $1.25 \mathrm{E}-04$ & $2.02 E-02$ & 4.49E-04 \\
\hline 8.5 & 4.61 & $<1.4 \mathrm{E}-02$ & 4.82E-04 & $1.56 \mathrm{E}-02$ & 9.51E-03 \\
\hline 9 & 4.40 & $<1.4 \mathrm{E}-02$ & 1.33E-03 & 2.32E-02 & $3.69 E-04$ \\
\hline 10.5 & 4.01 & $<1.4 E-02$ & 1.19E-03 & $2.55 \mathrm{E}-02$ & 1.63E-03 \\
\hline 11.5 & 4.31 & $<1.4 \mathrm{E}-02$ & $3.00 \mathrm{E}-03$ & $3.24 \mathrm{E}-02$ & $3.97 E-04$ \\
\hline 12.5 & 4.36 & $<1.4 \mathrm{E}-02$ & 2.89E-03 & $3.20 \mathrm{E}-02$ & $1.28 \mathrm{E}-03$ \\
\hline 13.5 & 4.09 & $<1.4 \mathrm{E}-02$ & $2.61 E-03$ & $2.99 \mathrm{E}-02$ & $7.07 \mathrm{E}-04$ \\
\hline 14.5 & 3.77 & $<1.4 \mathrm{E}-02$ & $9.76 \mathrm{E}-04$ & 1.42E-02 & $7.59 \mathrm{E}-03$ \\
\hline 15.5 & 4.83 & $<1.4 \mathrm{E}-02$ & $1.45 \mathrm{E}-04$ & 3.75E-03 & $7.24 \mathrm{E}-04$ \\
\hline 16.5 & 4.68 & $<1.4 \mathrm{E}-02$ & $9.03 E-05$ & $1.78 E-03$ & 2.68E-03 \\
\hline 17.5 & 4.61 & $<1.4 \mathrm{E}-02$ & $<3.6 \mathrm{E}-05$ & 2.13E-03 & $5.36 \mathrm{E}-03$ \\
\hline 18.5 & 4.05 & $<1.4 \mathrm{E}-02$ & $<3.6 \mathrm{E}-05$ & $<1.3 \mathrm{E}-04$ & $<3.6 \mathrm{E}-05$ \\
\hline 19 & 4.40 & $<1.4 \mathrm{E}-02$ & $<3.6 \mathrm{E}-05$ & $2.52 \mathrm{E}-03$ & $9.42 E-03$ \\
\hline 19.5 & $4: 33$ & $<1.4 \mathrm{E}-02$ & $<3.6 \mathrm{E}-05$ & $<1.3 \mathrm{E}-04$ & 2.12E-04 \\
\hline 20.5 & 4.61 & $<1.4 \mathrm{E}-02$ & $<3.6 \mathrm{E}-05$ & $1.45 \mathrm{E}-02$ & $8.24 E-03$ \\
\hline 21.5 & 3.69 & $<1.4 \mathrm{E}-02$ & $<3.6 \mathrm{E}-05$ & 1.13E-03 & $3.68 \mathrm{E}-03$ \\
\hline 22.5 & 4.86 & $<1.4 \mathrm{E}-02$ & $<3.6 \mathrm{E}-05$ & 1.43E-03 & 1.76E-03 \\
\hline 23.5 & 4.22 & $<1.4 \mathrm{E}-02$ & $<3.6 \mathrm{E}-05$ & 1.26E-03 & 7.03E-03 \\
\hline 24.5 & 3.69 & $<1.4 \mathrm{E}-02$ & $<3.6 \mathrm{E}-05$ & $2.54 \mathrm{E}-03$ & $3.11 E-03$ \\
\hline 25.5 & 5.16 & $<1.4 \mathrm{E}-02$ & $<3.6 \mathrm{E}-05$ & 4.07E-04 & 3.17E-03 \\
\hline 25.75 & 3.91 & $<1.4 \mathrm{E}-02$ & $<3.6 \mathrm{E}-05$ & $<1.3 \mathrm{E}-04$ & $1.21 E-03$ \\
\hline 26.5 & 3.76 & $<1.4 \mathrm{E}-02$ & $<3.6 \mathrm{E}-05$ & 1:56E-03 & 1.03E-02 \\
\hline 27.5 & 4.53 & $<1.4 \mathrm{E}-02$ & $<3.6 \mathrm{E}-05$ & $1.92 \mathrm{E}-03$ & $2.19 \mathrm{E}-02$ \\
\hline 28.5 & 5.51 & $<1.4 \mathrm{E}-02$ & $<3.6 \mathrm{E}-05$ & $1.48 \mathrm{E}-03$ & $7.89 \mathrm{E}-03$ \\
\hline 29.5 & 4.62 & $<1.4 \mathrm{E}-02$ & $<3.6 \mathrm{E}-05$ & $3.31 E-04$ & 3.17E-03 \\
\hline 30.5 & 3.94 & $<1.4 \mathrm{E}-02$ & $<3.6 E-05$ & $<1.3 E-04$ & $1.75 E-03$ \\
\hline
\end{tabular}




\begin{tabular}{|c|c|c|c|c|c|}
\hline \multirow[b]{2}{*}{ Depth (ft) } & \multirow{2}{*}{$\begin{array}{c}\text { Sample } \\
\text { Weight (gm) }\end{array}$} & \multicolumn{4}{|c|}{$\mathrm{mg} / \mathrm{kg}$} \\
\hline & & c-dce & ccl4 & tce & pce \\
\hline 31 & 4.62 & $<1.4 \mathrm{E}-02$ & $<3.6 \mathrm{E}-05$ & $<1.3 \mathrm{E}-04$ & 3.72E-04 \\
\hline 31.5 & 4.07 & $<1.4 \mathrm{E}-02$ & $<3.6 \mathrm{E}-05$ & $<1.3 \mathrm{E}-04$ & $3.41 E-04$ \\
\hline 32.5 & 4.24 & $<1.4 \mathrm{E}-02$ & $<3.6 E-05$ & 1.15E-03 & $1.29 \mathrm{E}-02$ \\
\hline 33.5 & 5.11 & $<1.4 \mathrm{E}-02$ & $<3.6 \mathrm{E}-05$ & $<1.3 E-04$ & 1.70E-04 \\
\hline 34.5 & 3.35 & $<1.4 \mathrm{E}-02$ & $<3.6 \mathrm{E}-05$ & $6.50 \mathrm{E}-03$ & 3.32E-03 \\
\hline 35.5 & 3.75 & $<1.4 \mathrm{E}-02$ & $<3.6 \mathrm{E}-05$ & $<1.3 \mathrm{E}-04$ & $3.90 \mathrm{E}-04$ \\
\hline 36 & 4.48 & $<1.4 \mathrm{E}-02$ & $<3.6 \mathrm{E}-05$ & $<1.3 E-04$ & 1.48E-03 \\
\hline 37 & 3.91 & $<1.4 \mathrm{E}-02$ & $<3.6 \mathrm{E}-05$ & $<1.3 E-04$ & $2.25 E-04$ \\
\hline 38.5 & 3.52 & $<1.4 \mathrm{E}-02$ & $<3.6 \mathrm{E}-05$ & 4.31E-03 & 3.54E-03 \\
\hline 39 & 4.10 & $<1.4 \mathrm{E}-02$ & $<3.6 \mathrm{E}-05$ & $<1.3 \mathrm{E}-04$ & $2.65 E-04$ \\
\hline 40.5 & 3.92 & $<1.4 \mathrm{E}-02$ & $<3.6 \mathrm{E}-05$ & $5.38 \mathrm{E}-04$ & 4.62E-04 \\
\hline 42.5 & 4.86 & $<1.4 \mathrm{E}-02$ & $<3.6 \mathrm{E}-05$ & 1.62E-03 & $6.73 \mathrm{E}-03$ \\
\hline 45 & 3.87 & $<1.4 \mathrm{E}-02$ & $<3.6 \mathrm{E}-05$ & $<1.3 E-04$ & $1.72 E-04$ \\
\hline 47 & 3.62 & $<1.4 \mathrm{E}-02$ & $<3.6 \mathrm{E}-05$ & $2.09 E-03$ & $9.13 E-04$ \\
\hline 48 & 4.15 & $<1.4 \mathrm{E}-02$ & $<3.6 \mathrm{E}-05$ & $<1.3 \mathrm{E}-04$ & $3.00 E-04$ \\
\hline 48.5 & 4.50 & $<1.4 \mathrm{E}-02$ & $<3.6 E-05$ & $<1.3 E-04$ & $<3.6 \mathrm{E}-05$ \\
\hline 49 & 4.13 & $<1.4 \mathrm{E}-02$ & $<3.6 \mathrm{E}-05$ & $<1.3 \mathrm{E}-04$ & $<3.6 \mathrm{E}-05$ \\
\hline 50.5 & 4.40 & $<1.4 E-02$ & $<3.6 \mathrm{E}-05$ & $9.78 \mathrm{E}-04$ & 3.98E-03 \\
\hline 51.5 & 3.86 & $<1.4 E-02$ & $<3.6 \mathrm{E}-05$ & $<1.3 E-04$ & $1.29 E-04$ \\
\hline
\end{tabular}




\section{Monitoring Well Installation}

Three monitoring wells, TCM,4, TCM5, and TCM8, were installed through a hollow stem auger. A 4 1/2 " diameter hole was augered 20 feet for the installation of each monitoring well. Two inch diameter Schedule 40 PVC casing and slotted well screen was used to construct each well. An artificial filter pack of sand was tremied into the hole using the hollow stem augers. Bentonite pellets were used to complete the well to the surface. Table 2 and Figures $2-4$ contain the well construction details for eâch well. After the wells were installed they were developed using air pumping and a submersible electric pump until the water was clear, $<15$ NTU.

Table 2 Well construction details for monitoring wells TCM4, TCM5, and TCM8 and pilot hole TGSC-2A.

\begin{tabular}{|l|c|c|c|c|c|c|c|c|}
\hline Well ID & $\begin{array}{c}\text { SRS } \\
\text { North } \\
\text { (ft) }\end{array}$ & $\begin{array}{c}\text { SRS East } \\
\text { (ft) }\end{array}$ & $\begin{array}{c}\text { Surface } \\
\text { Elev. } \\
\text { (ft, msl) }\end{array}$ & $\begin{array}{c}\text { Depth to } \\
\text { Top of } \\
\text { Screen } \\
\text { (ft) }\end{array}$ & $\begin{array}{c}\text { Length } \\
\text { of } \\
\text { Screen } \\
\text { (ft) }\end{array}$ & $\begin{array}{c}\text { Depth to } \\
\text { Top of } \\
\text { Filter } \\
\text { Pack (ft) }\end{array}$ & $\begin{array}{c}\text { Depth to } \\
\text { Bottom } \\
\text { of Filter } \\
\text { Pack (ft) }\end{array}$ & $\begin{array}{c}\text { Total } \\
\text { Drilled } \\
\text { Depth } \\
\text { (ft) }\end{array}$ \\
\hline TGSC-2A & 71094.12 & 16173.29 & 97.27 & n.a. & n.a. & n.a. & n.a. & 52 \\
\hline TCM4 & 71140.75 & 16174.67 & 96.83 & 2.25 & 15 & 1 & 20 & 20 \\
\hline TCM5 & 71122.37 & 16174.26 & 97.11 & 2.25 & 15 & 1 & 20 & 20 \\
\hline TCM8 & 71125 & 16130 & 97 & 2.25 & 15 & 1 & 20 & 20 \\
\hline
\end{tabular}

\section{References}

ETI, 1996. ETI Reference : 31054.10, EnviroMetal Technologies, Inc., Feasibility Study Report, CVOC Iron Degradation Study Using Groundwater from the TNX Area, Savannah River Technology Center, Aiken, South Carolina, July 1996.

Phifer, M.A., F.C. Sappington, M.E. Denham, 1997. TNX GeoSiphon Cell (TGSC-1) Phase 1 Deployment / Demonstration Final Report (U), WSRC-TR-98-00032, Rev.0. Westinghouse Savannah River Company, Aiken South Carolina, 29808.

EPA, 1995. Test Methods for Evaluating Solid Waste, Method 5021 Volatile Organic Compounds in Soils and Other Solid Matrices Using Equilibrium Headspace Analysis. EPA Publication SW 846.

Looney, B. B., C. A. Eddy, and W. R. Sims, 1993. Evaluation of Headspace Method for Volatile Constituents in Soils and Sediments. In Measuring and Interpreting VOCs in Soils: State of the Art and Research Needs, US Environmental Protection Agency, Environmental Monitoring Systems Laboratory, Las Vegas NV 89193. 
Figure 1 Geophysical log and trichloroethylene profile for TGSC-2A.

TGSC-2A,

(SRS North 71094 SRS East 16173, Elev. 97.27 feet above MSL)

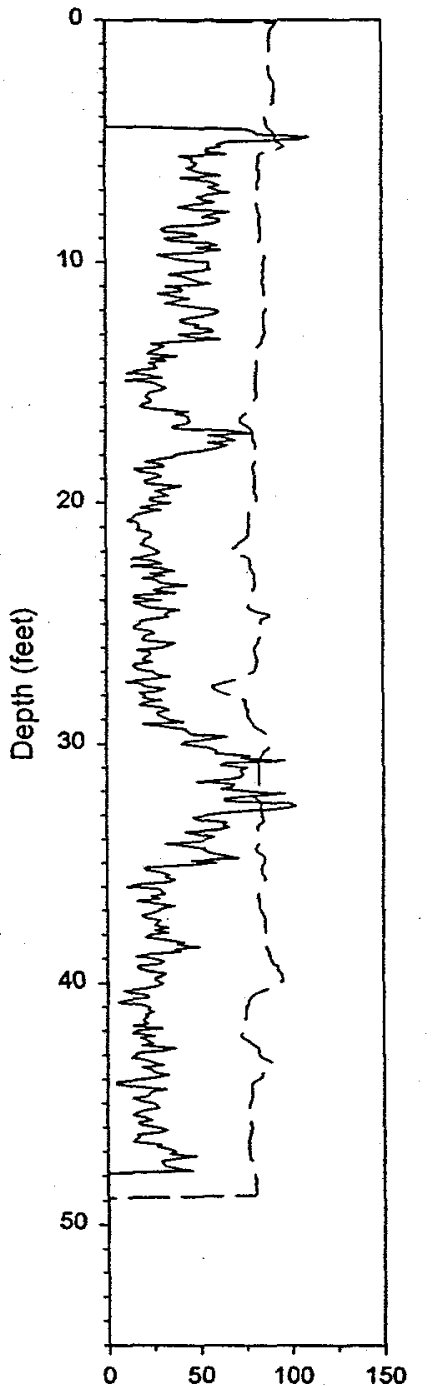

Natural Gamma Ray (GAPI)

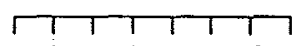

$\begin{array}{llllllll}0 & 2 & 4 & 6 & 8 & 10 & 12 & 14\end{array}$ Caliper (inches)

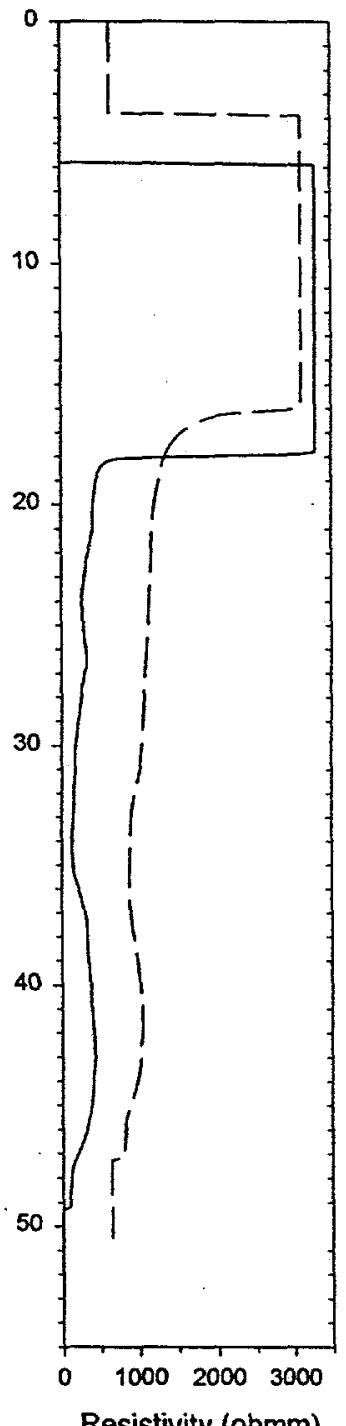

Resistivity (ohmm)

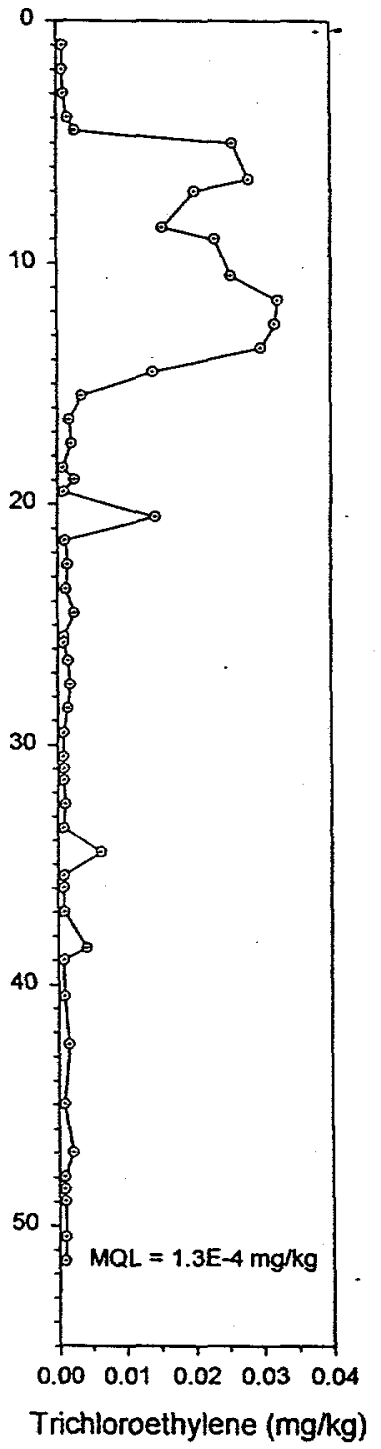

Resistivity $16 \mathrm{~N}$

- Resistivity 64N 
Figure 2 Monitoring well construction diagram for monitoring well TCM4.

OSR 30-Sn (Rev 4-7-97)

\section{Monitoring Well Construction Diagram}

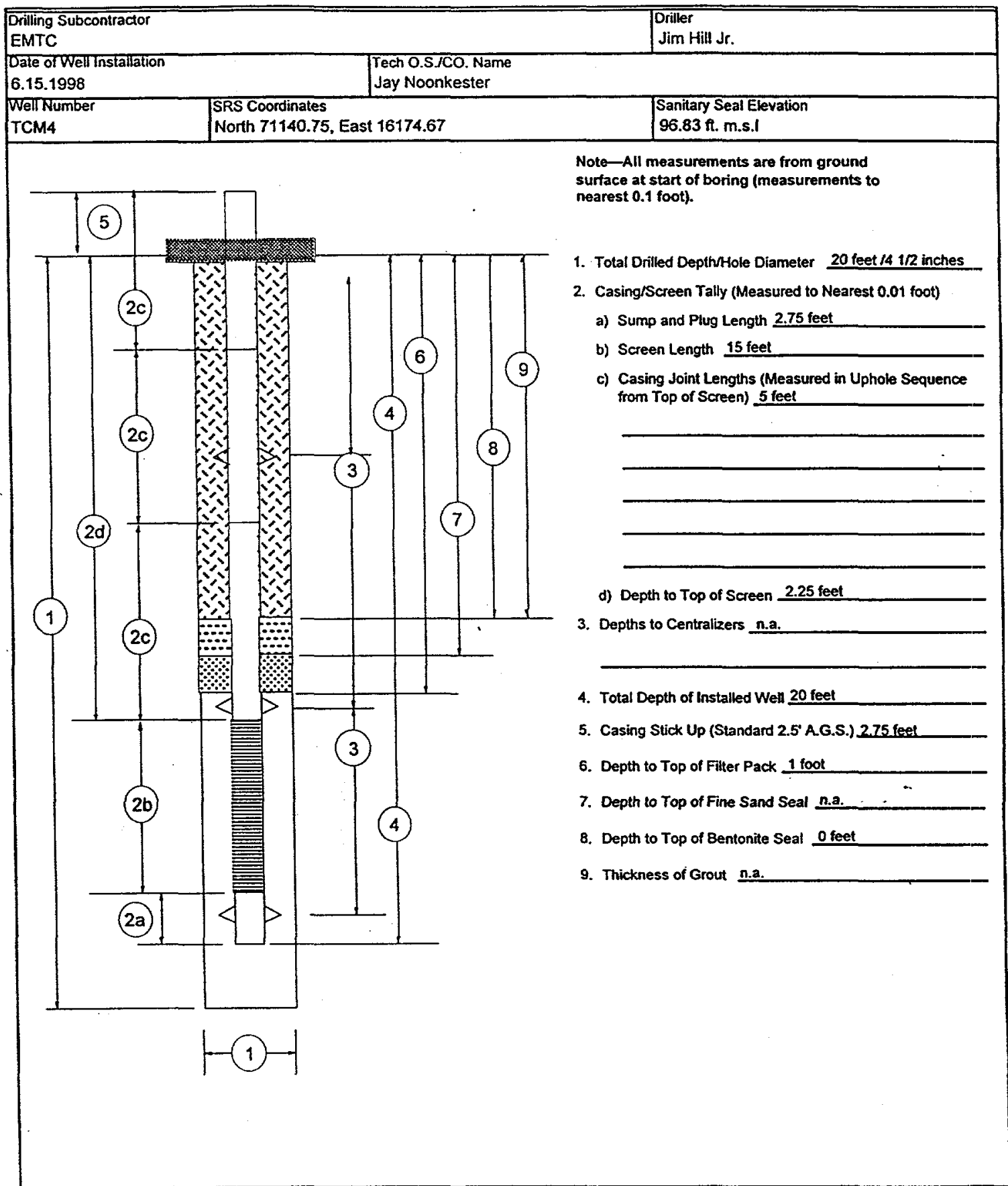


Figure 3 Monitoring well construction diagram for monitoring well TCM5.

OSR 30.5u (Rev 4.7.97)

\section{Monitoring Well Construction Diagram}

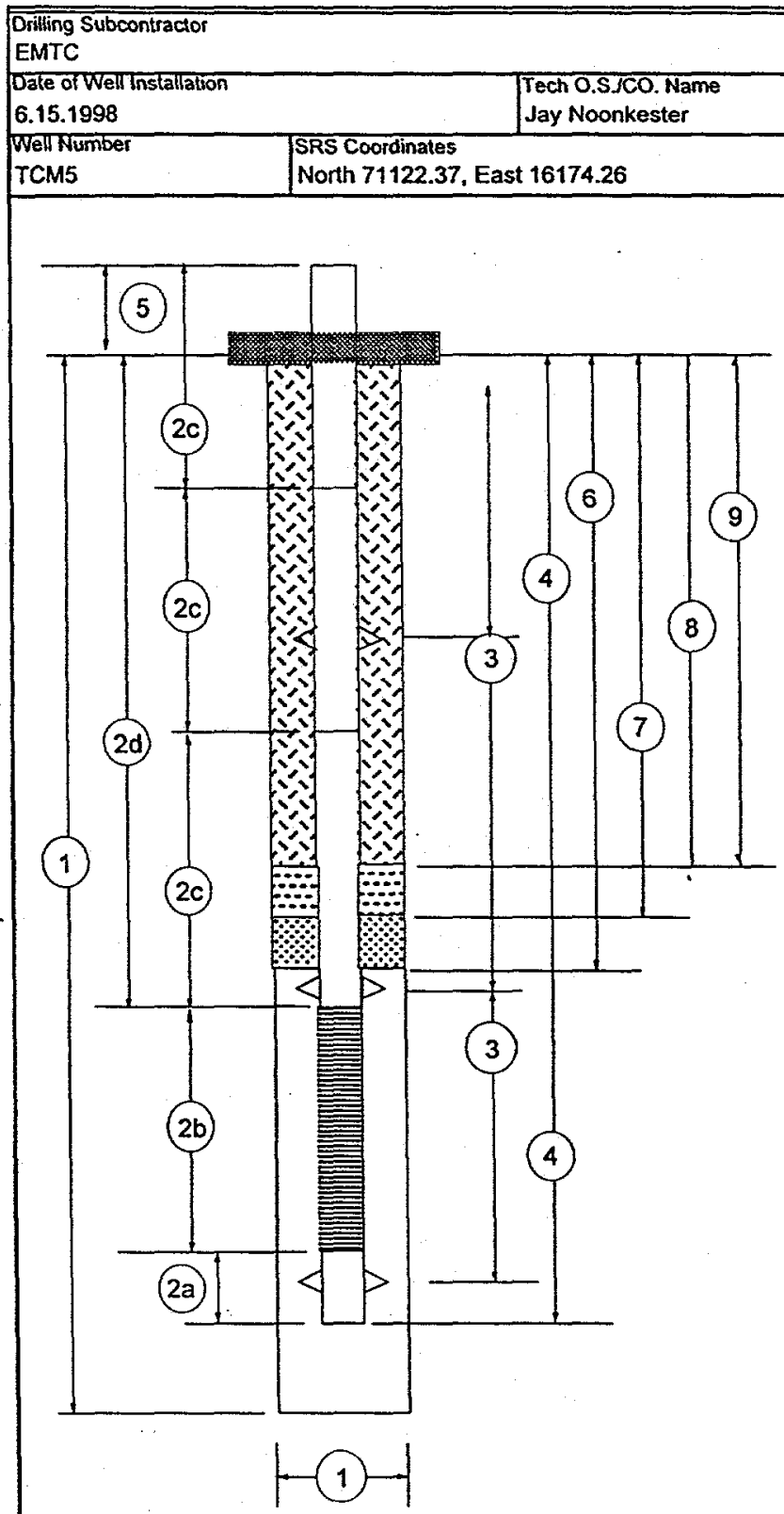

Noto-All measurements are from ground surface at start of boring (measurements to nearest 0.1 foot)

1. Total Drilled Depth/Hole Diameler 20 feet $/ 41 / 2$ inches

2. Casing/Screen Tally (Measured to Nearest 0.01 foot)

a) Sump and Pug Length 2.75 feet

b) Screen Length 15 feet

c) Casing Joint Lengths (Measured in Uphole Sequence from Top of Screen) 5 feet

d) Depth to Top of Screen $2.25 \mathrm{feet}$

3. Depths to Centratizers n.a.

4. Total Depth of Installed Well 20 feet

5. Casing Stick Up (Standard 2.5 A.G.S.) 275 feet

6. Depth to Top of Fitter Pack 1 foot

7. Depth to Top of Fine Sand Seal n.a.

8. Depth to Top of Bentonite Seal 0 feet

9. Thickness of Grout n.a. 
Figure 4 Monitoring well construction diagram for monitoring well TCM8.

OSR Ja-SA (Rev 4-7-97)

\section{Monitoring Well Construction Diagram}

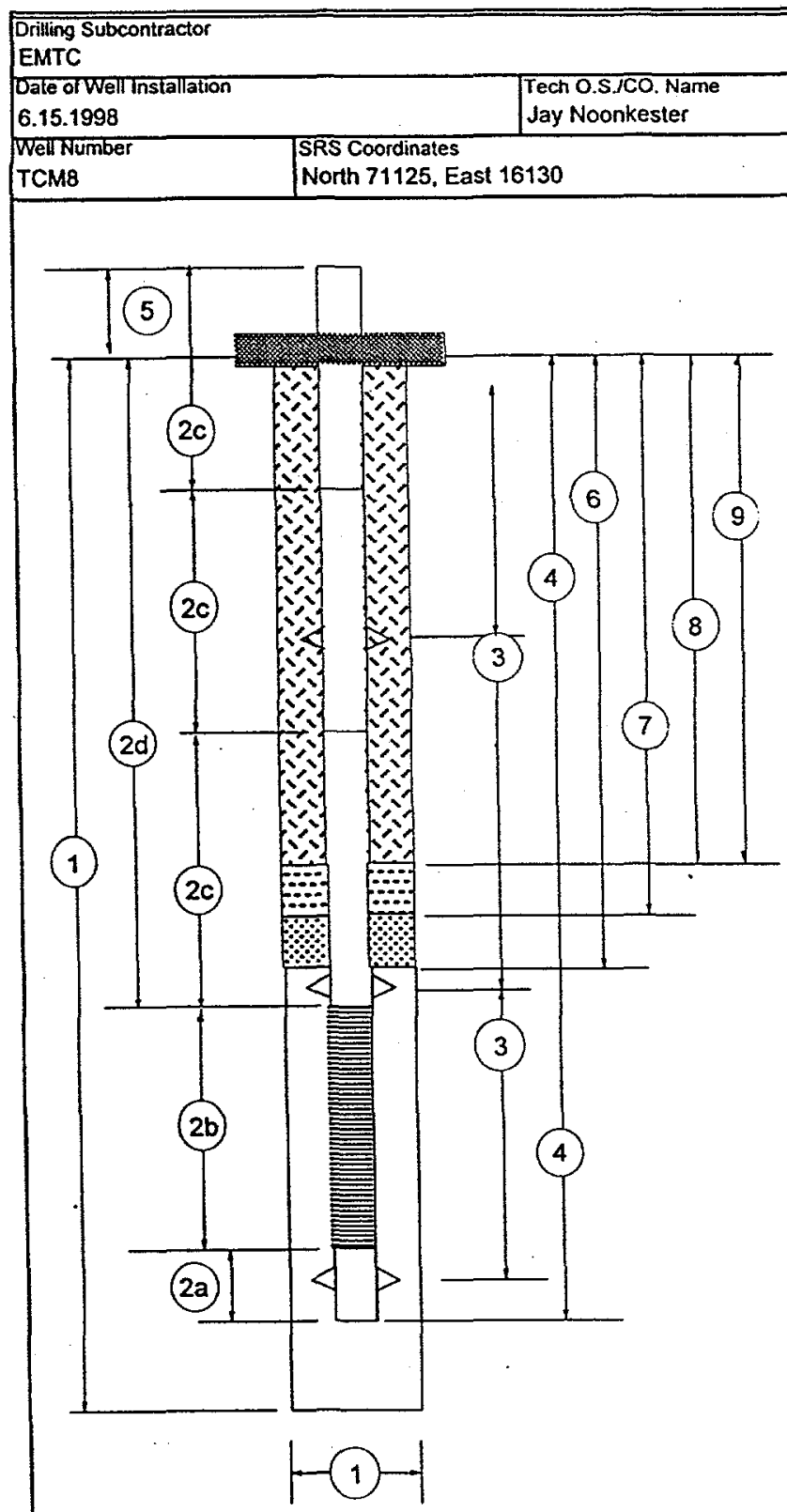

EMTC Jim Hill Jr.

Note-All measurements are from ground surface at start of boring (measurements to nearest 0.1 foot).

1. Total Drilled Depth/Hole Diameter 20 feet $/ 41 / 2$ inches

2. Casing/Screen Tally (Measured to Nearest 0.01 foot)

a) Sump and Plug Length $\mathbf{2 . 7 5}$ feet

b) Screen Length 15 feet

c) Casing Joint Lengths (Measured in Uphole Sequence from Top of Screen) 5 feet

d) Depth to Top of Screen 2.25 feet

3. Depths to Centralizers n.a.

4. Total Depth of installed Well 20 feet

5. Casing Stick Up (Standard $2.5^{\circ}$ A.G.S.) 275 f

6. Depth to Top of Fitter Pack 1 foot

7. Depth to Top of Fine Sand Seal n.a.

8. Depth to Top of Bentonite Seal ofeet

9. Thickness of Grout n.a. 
Appendix A

Field Geologic Log for

Pilot Hole TGSC-2A 
Field Geologic Log

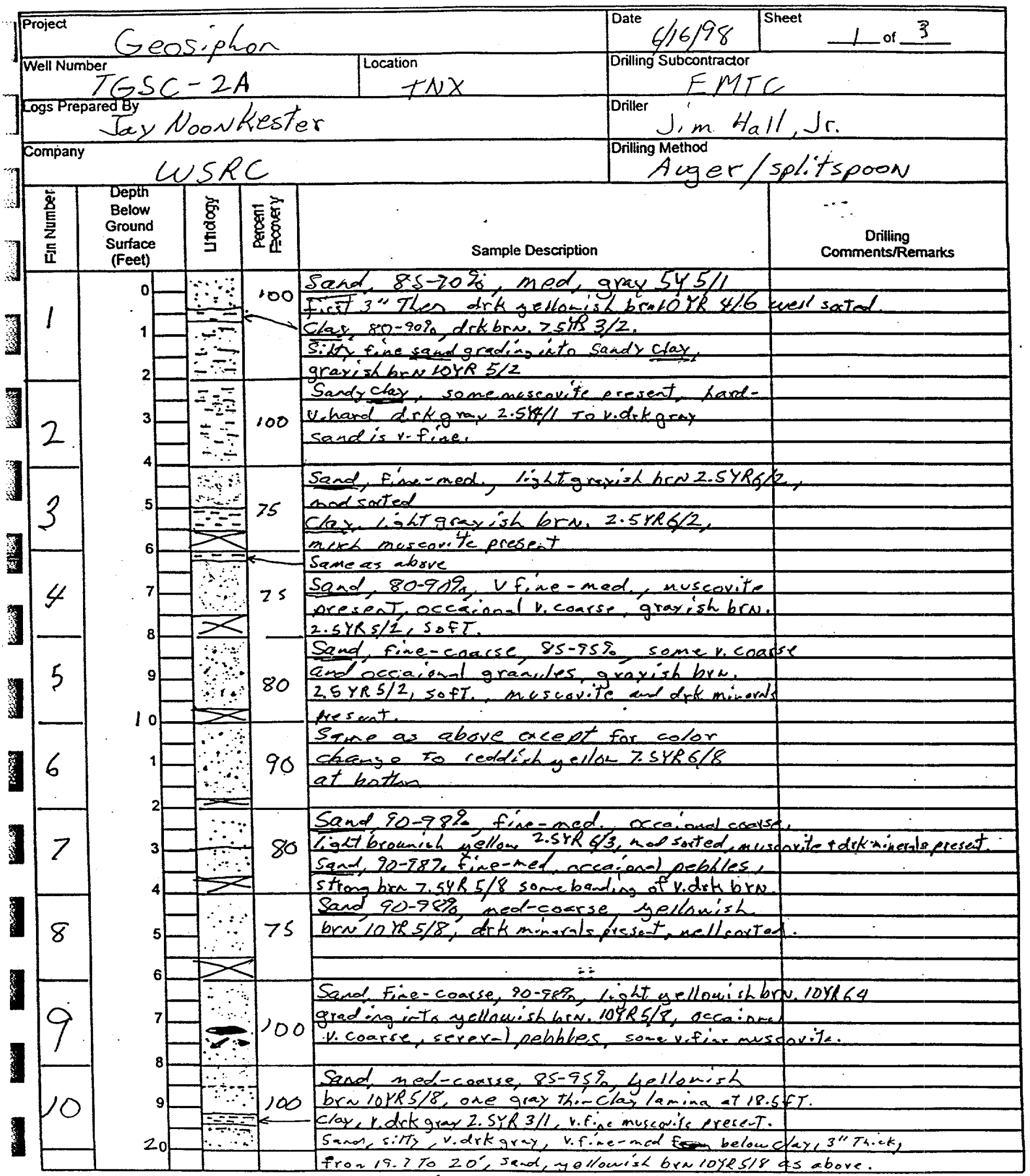




\section{Field Geologic Log}

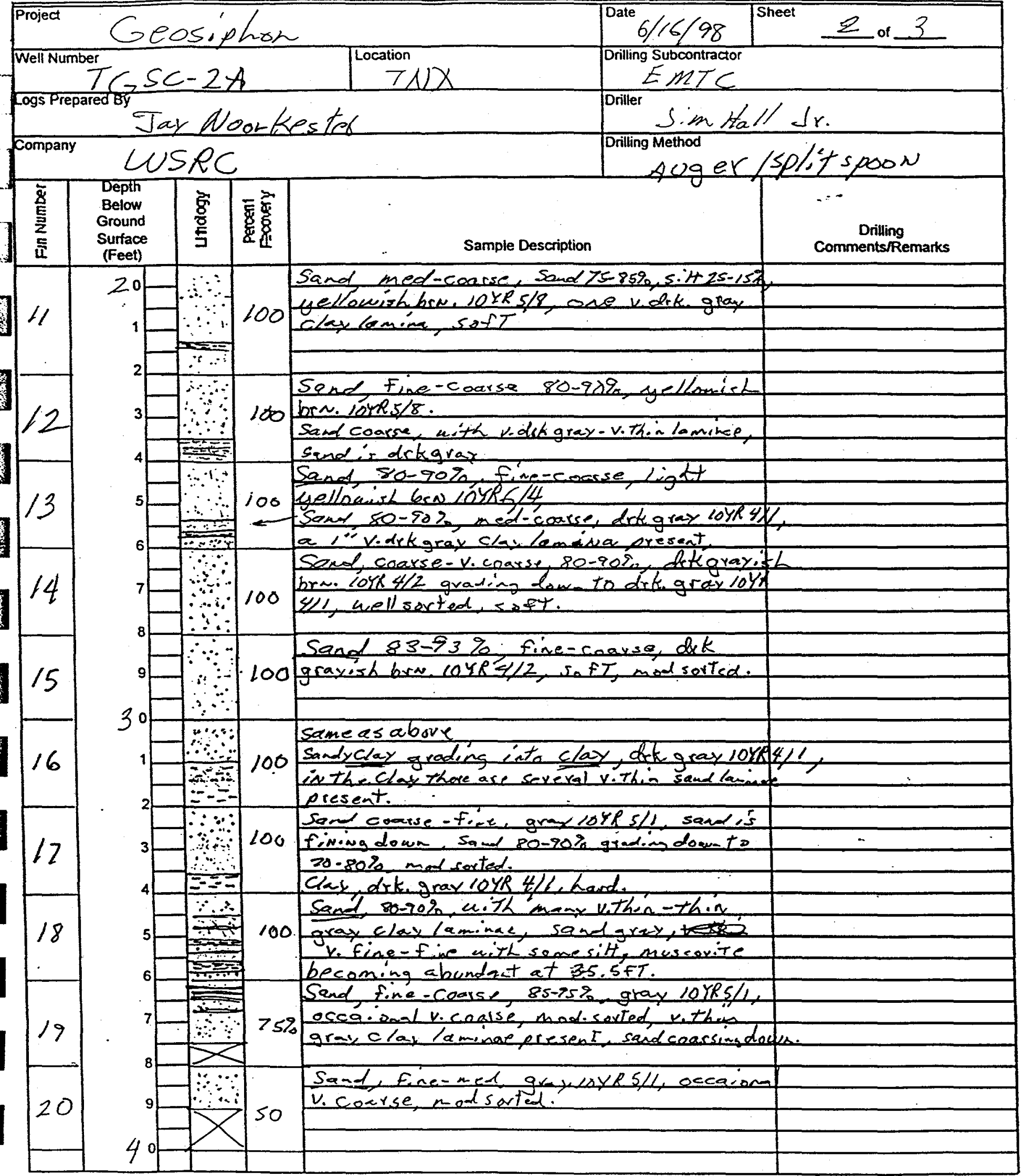




\section{Field Geologic Log}

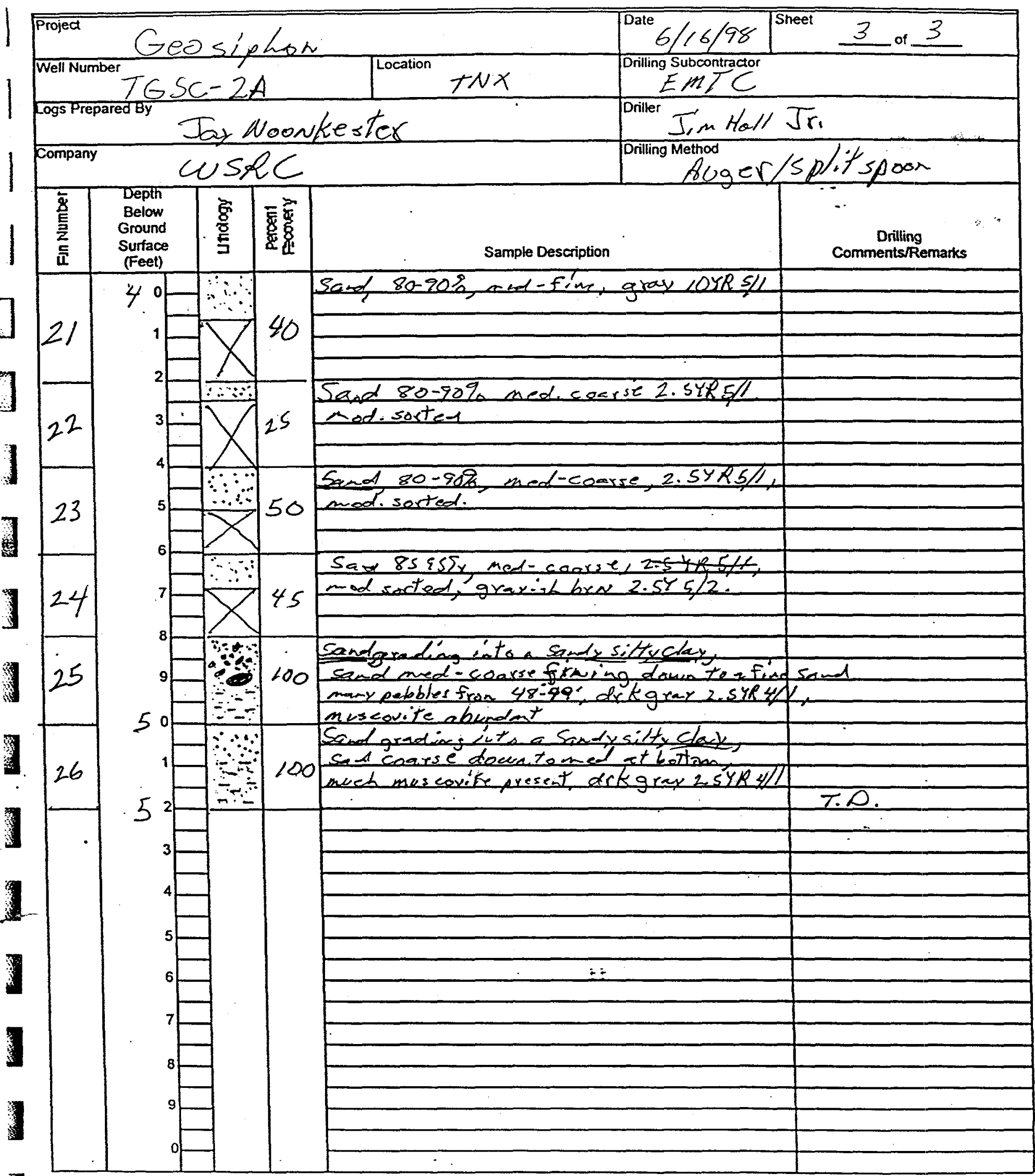

